\title{
Fruit and Vegetable Consumption among Medical Students in an Egyptian University: Knowledge, Practice, and Attitude towards Accessible Healthy Food
}

\author{
Sahar Mohamed Sabbour ${ }^{1}$, Wafaa Mohamed Hussein ${ }^{1}$,Ghada Essam Eldin Amin ${ }^{1}$ \\ ${ }^{1}$ Department of Community Environmental and Occupational medicine, Faculty of Medicine, \\ Ain Shams University.
}

Received :July $2017 \quad$ Accepted : October 2017

\section{Abstract}

Background: Diet rich in fruits and vegetables is associated with a decreased risk for many chronic diseases. Several studies have shown low fruit and vegetable consumption among university students. The burden of disease associated with inadequate nutrition negatively affects their health. Objectives: Assessment of fruit and vegetable (F\&V) consumption among medical students, knowledge of daily requirements, perceptions of benefits, barriers and motives for $(\mathrm{F} \& \mathrm{~V})$ consumption and identify their acceptance of accessible healthy food.

Methods: A self-administered questionnaire adapted from Food Attitudes and Behaviors Survey (FAB) was completed by 473 students. Scores were calculated for knowledge, benefits, barriers and motives. Food events were done in between teaching sessions and in the faculty campus where healthy stuffs were provided. Students' acceptance of healthy food was assessed by those who got food items during events and those who expressed willingness to try food stuffs in future events. Results: Knowledge of the recommended five daily servings for $\mathrm{F} \& \mathrm{~V}$ was recalled by $8.2 \%$ of students, $110(23.26 \%)$ consumed 5 servings of $\mathrm{F} \& \mathrm{~V}$ daily. Mean knowledge score percent was $28.11 \pm 26.69$ and higher among males $(\mathrm{P}<0.01)$. Mean benefit score percent was $83.9 \pm 11.7$, for barriers $61.75 \pm 16.55$ and for motivation $59.79 \pm 19.83$. Males as well as smokers had higher mean barrier score $(\mathrm{P}<0.01)$. Healthy food items were tried by $35.7 \%$ of students. Fresh orange juice, green salad and banana were the most requested items. Almost $44 \%$ expressed willingness to try healthy food in future events. Conclusion and recommendation: Medical students have infrequent $\mathrm{F} \& \mathrm{~V}$ consumption; however, they have motives to consume them. A high frequency of students accepts presence of healthy food environment. Wider access is recommended.

Key words: Fruits and vegetables, consumption, knowledge, motives, barriers, healthy food

Correspondent author: Name: Sahar Mohamed Sabbour Email:sabbour_s@hotmail.com

\section{Introduction}

A diet high in fruits and vegetables $(\mathrm{F} \& \mathrm{~V})$ is associated with a broad spectrum of health benefits and a decreased risk of many chronic diseases and some cancers. It also helps in weight management ${ }^{(1)}$. Young adults at the age between 18 and 24 years are in a stage of life in which they make their own dietary choices and are continuously challenged to make healthy ones ${ }^{2}$. Health hazards of inadequate $(\mathrm{F} \& \mathrm{~V})$ consumption can be observed at such young age and affects health negatively. Low fruit and vegetables consumption was significantly associated with dyslipidaemia among university students in Fayoum ${ }^{3}$. Moreover, Egypt Demographic and Health Survey in 2014 reported that overweight and obesity were prevalent among $42.3 \%$ of girls and $30.1 \%$ of boys aged 15-19 years ${ }^{4}$. 
The problem of unhealthy eating behavior among youth is of importance as it influences their risk of many chronic diseases later on.

The average estimated needs/day varies according to age, gender and level of physical activity for adults aged 18-30 years that range between 1800-3200 Kcal/day ${ }^{5}$.

The recommended daily intake of fruits and vegetables based on an average 2000 kcal diet is two cup equivalents of fruits and two and a half cup equivalents of vegetables. One cup equals approximately one medium apple, eight strawberries, 12 baby carrots, or one large tomato as examples. Recommended intake is often expressed as five servings of fruits and vegetables daily ${ }^{1,6}$.

An assessment of $\mathrm{F} \& \mathrm{~V}$ intake in 9 countries in the Eastern Mediterranean region revealed that $70 \%$ of the adult population $(15-65$ years $)$ consume less than the recommended five servings per day. ${ }^{1}$

Fruit and vegetable consumption studied among adolescents in eleven countries in the Eastern Mediterranean Region showed that only $19.4 \%$ reported consuming $\mathrm{F} \& \mathrm{~V}$ $\geq 5$ times $/ \mathrm{d}^{7}$.

A population based survey (STEPS) conducted in Egypt on 5300 adults aged 15-65 years, revealed that $95.6 \%$ of adults aged 25-64 years eat less than 5 servings of fruits and or vegetables/day ${ }^{8}$.

Fruit and vegetable consumption has been invariably reported to be low among adolescents and young adults. A fairly low frequency of adequate consumption of $\mathrm{F} \& \mathrm{~V} \quad(21.7 \%)$ was found among adolescents in Sohag, Upper Egypt ${ }^{(9)}$. In Mansoura, Lower Egypt, a study of the dietary habits of 927 secondary school students showed that $29 \%$ consume fruits and $78.2 \%$ consume raw vegetables on a daily basis however the number of daily servings was not specified ${ }^{10}$. Among a sample of 2875 Egyptian university students assessing their healthy nutrition and physical activity guidelines, fresh fruits were consumed on daily basis by $31.4 \%$ of participants, while $40.2 \%$ consume salads and raw vegetables daily. ${ }^{11}$ Studies involving young adults from a number of developing countries have shown similarly low F\&V consumption (23\% in Brazil, $26.5 \%$ in Malaysia and $37 \%$ in Nigeria) ${ }^{12,13,14}$.

$\mathrm{F} \& \mathrm{~V}$ consumption remains low among university students. In a Saudi Arabian University F\&V consumption was $22 \%{ }^{15}$. Another study found that $F \& V$ consumption of at least 5 daily servings was $34.7 \%$ with a significantly higher consumption among females ${ }^{16}$.

Many factors affect students $F \& V$ eating habits. Correct knowledge of F\&V recommended daily intake doesn't always guarantee adherence to it. A recent Saudi Arabian study showed that despite the fact that $72.2 \%$ of University students had correct information about the daily $\mathrm{F} \& \mathrm{~V}$ WHO recommendations; only $3.27 \%$ actually consumed 5 servings or more daily ${ }^{17}$.

An ecological framework previously described by Story et al, 2008 reveals that not only knowledge but also the environmental context influence food choices and eating behavior. These include the social environment (as family, friends and peers), the physical environments (as schools, work sites and restaurants) and the macro-level environments as food marketing ${ }^{18}$. A similar group of factors including living with the family, planning daily menu by themselves, fitness consciousness and regular exercise were found to encourage more $\mathrm{F} \& \mathrm{~V}$ consumption among university students ${ }^{17}$. An Egyptian study found that those from higher social class were twice as likely to consume vegetables and nearly 4 times as likely to consume fruits daily compared to low social class ${ }^{10}$. The presence of a healthy food environment in campus could 
enhance better food choices among students ${ }^{2}$. Environmental strategies are one component in the ecological framework described by Story et al, $2008^{18}$ which can alone or combined with other interventions influence students eating behavior. Environmental influences include food availability, price, promotion, social norms and role models ${ }^{(19,20)}$. This study investigated the following research questions: Do medical students know the recommended daily requirements of $\mathrm{F} \& \mathrm{~V}$, what is their actual consumption, what motivates them to consume $F \& V$ and what are their perceived benefits and barriers. Will students accept the presence of a healthy food environment and what are their preferred food choices?

The aim of the current study is to determine students' nutritional knowledge regarding the recommended daily requirements of fruit and vegetable, to assess the current fruit and vegetable consumption among medical students, to identify motives, perceived benefits, and perceived barriers in fruit and vegetable consumption and to assess students' acceptance of presence of a healthy food environment and their preferred food choices.

\section{Method}

Study design and setting: This cross sectional study involved 473 medical students at the Faculty of medicine Ain Shams University during the academic year 2012-2103.

Sample size: Calculations were based on a prevalence of $21.7 \%$ for adequate fruit and vegetable consumption among 300 adolescents in Egypt ${ }^{9}$ with $95 \%$ confidence level and $80 \%$ power, the estimated required sample size was 483 using NCSS PASS 11 statistical package.

A total of 550 questionnaires (to compensate for non-response and incomplete responses) were distributed, 508 questionnaires were returned of which
35 questionnaires were excluded due to largely missing data resulting in a final sample of 473.

Tool: A self-administered questionnaire adapted from FAB survey, $2009^{6}$ was distributed to students during Healthy food events. The department of Community, Environmental and Occupational medicine at Ain Shams University has initiated "Healthy food events" in attempt to promote healthy eating choices among medical students and to identify their acceptance of a healthy food environment.

Access to Healthy food was provided physically and economically (low price) in between teaching sessions for 4th year medical students on Wednesdays each week during the first semester of the academic year 2012-2013 mounting up to 13 events. Two other healthy food events were organized in the faculty campus to extend access to students from all other grades based on their availability. The initiative was based on providing a selected list of food items including whole fresh vegetables and fruits, salads, sandwiches and fresh fruit juices. Acceptance of a healthy food environment was indicated by student's response to the following questions: (1) Have you ever tried getting food from the healthy food days? (2) Are you willing to try healthy food stuffs or to participate in organizing healthy food days in future events?

Questionnaire description and validation: The questionnaire included sections on: participant 's demographic characteristics, nutritional knowledge, attitude towards eating $F \& V$ that asked about benefits, barriers and motives, consumption of $\mathrm{F} \& \mathrm{~V}$ and lastly a section about participation in the healthy food events.

Examples of how much counts as 1 cup or 1 serving of $\mathrm{F} \& \mathrm{~V}$ was included in the questionnaire section adapted from $\mathrm{FAB}$ survey, $2009^{6}$. It was meant to guide students recall correctly their average daily consumption of $\mathrm{F} \& \mathrm{~V}$. 
Questionnaire forms were kept in English language to ensure validity of the adapted questions. The researchers established face and content validity before conducting the study by reviewing the questionnaire items with faculty. Two questions that asked about self rating of health status were omitted because of non specific responses.

Study population: It included a convenient sample of medical students in the $4^{\text {th }}$ grade during attending the community medicine round as well as medical students from other educational grades. The later were enrolled in the study based on their availability during the healthy food events organized outdoors in the faculty venue.

Scoring of variables: Scores were created for the following aspects: Knowledge, Benefits, Motivation and Barriers.

Knowledge (4 questions: average calorie needs for an adult, recommended daily servings of fruits\& vegetables, recommended daily number of cups of fruits and recommended daily number of cups of vegetables).

For nutrition knowledge questions, answers to questions were graded one for correct answer and Zero for the incorrect with a total score of 4 .

Correct answers for knowledge sections were set as follows: Recommended average calorie needs for an adult $=1800$ $3200 \mathrm{kcal} /$ day $^{5}$. Recommended number of daily servings of fruits and vegetables $=5$. Recommended fruit intake daily $=2-3$ cups of fruits/day. Recommended vegetable intake daily $=2-3$ cups of vegetables/day For the sections of perceived benefits, barriers and motivation a likert scale of 5 categories was used where $5=$ strongly agree and $1=$ strongly disagree). Benefits: (5 statements for fruits and 6 for vegetables with a total score of 55), motivation for consumption: (8 statements with a total score of 40), Barriers: (5 statements for fruits and 5 for vegetables with a total score of 50).
A summation of scores of all questions in each section was done for each student then divided by the total number of students. All scores were then multiplied by 100 and presented as percentages.

Data management and Statistical analysis: Data were statistically described in terms of mean \pm standard deviation, or frequencies (number of cases) and percentages when appropriate. Analysis was done using independent sample t-test for comparison of means. Chi squared test and Odds ratio for testing the association between categorical variables. Significance level was selected at $\mathrm{p} \leq 0.05$.Statistical analysis was done using SPSS version 22 for Microsoft Windows. During analysis, any student other than being a $4^{\text {th }}$ grade student was grouped in a separate category "other educational grades" as the aim was not to compare F\&V consumption and attitude in each educational grade, but rather to explore whether a $4^{\text {th }}$ grade student; being exposed to recurrent healthy food days with easier accessibility; would have different responses.

Ethical consideration: The study didn't include any additional procedures rather than the daily living activities. Verbal informed consent was witnessed and formally recorded. All questionnaire forms were anonymous.

\section{Results}

The sample included 473 students of whom $263(55.60 \%)$ were females. Their mean age was $20.47 \pm 1.35$ years. There were $59(12.47 \%)$ current smokers. Based on self-reported height and weight, $35.5 \%$ were categorized as overweight or obese $(\mathrm{BMI} \geq 25)$. Mean age of $4^{\text {th }}$ year students was $20.61 \pm 0.73$ while mean age of students from other grades was $20.24 \pm$ $1.95(\mathrm{p}=0.014)$. Detailed characteristics of the sample is in (table 1)

The least known knowledge in nutrition was the recommended number of daily servings of fruits and vegetables as only 39 
students $(8.25 \%)$ knew the correct answer (table 2).

When asked about the actual daily intake of $\mathrm{F} \& \mathrm{~V}$, nearly one quarter of students (24.5\% and $23.2 \%$ ) met the recommended daily amounts for fruit and vegetable respectively. Almost 10\% of students do not consume either item daily (table 3 ).

Groups and types of fruits and vegetables in each group were listed for students to choose the ones they mostly consume. The preferred vegetables being consumed by students based on their recall were: Non starchy vegetables: 366 (85.71\%), Leafy: 344 (80.56\%), Starchy: 325 (76.11\%). Most preferred fruits consumed were: Fresh fruits: $383(89.49 \%)$ and Fruit juices: $321(75 \%)$. then dried fruits: $212(49.53 \%)$ and canned: 202 (47.2\%).

Most students identified "being tasteless" $(60.68 \%)$ and "Quick spoilage" $(58.35 \%)$ as the main barriers to eating vegetables; while the main barriers to eating fruits were being chemically polluted $(50.95 \%)$, quick spoilage (49.26\%) and being expensive $(42.71 \%)$. Concerning motives, the first five statements mostly agreed by students indicate intrinsic motivation; Good for health (55.81\%), To improve physical health $(53.91 \%)$, To feel better about myself $(51.37 \%)$, A choice I really want to make $(46.93 \%)$ and to feel in control of myself (46.72\%) (Table 4).

The mean score percentages calculated for knowledge, benefits, motives and barriers towards consuming $\mathrm{F} \& \mathrm{~V}$ revealed the following : Benefits were given the highest score percent being $83.94 \%( \pm 11.68)$, followed by barriers $61.75 \%( \pm 16.55)$, motives $59.79 \%( \pm 19.83)$ and least mean score percent was for nutrition knowledge being $28.11 \%( \pm 26.69)$.

Students were categorized as those with adequate daily intake of $\mathrm{F} \& \mathrm{~V}$ and those without and were compared in respect to their mean knowledge, benefits, motives and barrier scores (Table 5). No association was found between the knowledge; motives, benefit and barrier scores of students and their adequate consumption for fruits and vegetables.

Knowledge and perceived barriers scores for fruit and vegetables consumption were significantly higher among males than females $(p<0.05)$. Students reporting good health status had significantly higher knowledge scores. Barriers score was significantly higher among smokers. Students currently on diet regimen have higher motivation score (Table 6a). Students who knew about healthy food events have shown a higher knowledge and benefit score and a lower barrier score $\mathrm{p}<0.05$ (Table 6b).

Students' personal characters such as educational grade, gender, body mass index, smoking and eating outdoors showed no association with $\mathrm{F} \& \mathrm{~V}$ consumption., knowledge about healthy food events was not associated with $\mathrm{F} \& \mathrm{~V}$ consumption reported by students. Students with adequate F\&V consumption were not significantly different from those with inadequate consumption regarding ever participating in healthy food events or willingness to participate in the future (Table 7).

Most students $(64.48 \%)$ were aware of the healthy food events organized by Community Medicine Department. The majority of them knew about it from friends $(47.5 \%)$, faculty staff $(33 \%)$ or posters $(19.5 \%)$.One hundred sixty nine students $(35.73 \%)$ ever tried buying healthy food at these events and 206 $(43.55 \%)$ are willing to try healthy food in future events while 207(43.76\%) expressed willingness to actively participate in organizing similar events in the future (Figure a)

Students eating habits largely influenced whether or not they bought healthy foods. Table (8) shows that, eating outdoors and being currently on a diet regimen was significantly associated with ever buying healthy foods during the events. 
Willingness to try healthy foods in future events was only significantly associated with being a $4^{\text {th }}$ grade student. Willing to actively adopt the initiative of healthy food events was significantly associated with female gender, eating outdoors and being on a diet.

Students were asked to list their preferred food choices to be available in healthy food events. Regarding fruit categories, fruit salad cups $(42.9 \%)$ and whole fruit; mainly banana $(44.8 \%)$ and apples $(40 \%)$ were the most frequently requested items by students. From the fresh vegetables, green salad plates (56\%), cherry tomato cups $(38.7 \%)$ and sliced carrots (31.5\%) were the most frequently requested items. Whole-grain bread sandwiches as tuna sandwiches $(43.3 \%)$, cottage cheese sandwiches $(31 \%)$ were the most desirable items in sandwiches.

Fresh orange juice was the most preferred type of juice listed by $(60.8 \%)$ of students.

\section{Discussion}

In this study we have assessed medical students' consumption of F\&V and response towards an initiative providing accessible healthy food items. The study revealed that consumption of $\mathrm{F} \& \mathrm{~V}$ tends to be low among students (23.3\%) and a low frequency of participants was not eating $\mathrm{F} \& \mathrm{~V}$ at all.

Few studies have explored students' F\&V consumption based on recommended daily intake, while others only reported whether or not student consume any amount of $\mathrm{F} \& \mathrm{~V}$ on daily basis. In either case, most studies have generally shown low F\&V consumption ranging between $10 \%$ and $37 \%$ 9, 12, 15, 14, 13, 21.22.

Similar to the findings of the present study, a cross sectional survey among undergraduates in 11 faculties at Assuit University showed that $21.2 \%$ and $22.8 \%$ consume fruits and vegetables respectively several times daily although the number of daily servings was not specified ${ }^{23}$.
Similar results were found in countries in the region. A Saudi Arabians study reported that $40.5 \%$ consume fresh fruits only twice a week and $48 \%$ consume vegetables once weekly, and $85.5 \%$ ate less than 3 servings on these days ${ }^{24}$.

Few studies found a high $F \& V$ consumption among students. One Saudi Arabian study reported that more than $50 \%$ of a sample of University students consumed at least 3 servings of vegetables and at least 2 servings of fruits/day. However more than one third of them were studying at the department of nutrition whose vegetable consumption was significantly higher than students of the non-nutrition departments ${ }^{20}$. Compared to the current study, a recent survey among 2875 undergraduate students in Assuit University showed higher consumption rates of fruits $31.4 \%$ and raw vegetables $40.2 \%{ }^{11}$.

Gender was not consistently associated with $\mathrm{F} \& \mathrm{~V}$ consumption across previous studies. The current study shows no association between gender and adequate consumption of $\mathrm{F} \& \mathrm{~V}$ in agreement with other studies ${ }^{12,17}$.

In contrast, some studies in Greece, Saudi Arabia and in the US revealed that females had more regular $\mathrm{F} \& \mathrm{~V}$ consumption ${ }^{16,25,26}$. A Turkish study showed that females had better attitude and motivation to eat adequate amounts of F\&V ${ }^{27}$. An Egyptian study reported significantly higher vegetables consumption among male university students, but no gender difference regarding fruit consumption ${ }^{23}$. In the present study, students' knowledge did not seem to affect their F\&V consumption. While male students had significantly higher knowledge score, it didn't positively influence their consumption. On the contrary, two studies detected an association between knowledge and consumption ${ }^{17,21}$.

However, F\&V consumption is not only determined by an individual's knowledge. 
Previous studies reported that perceived barriers significantly affected adolescents' fruit and vegetable intake ${ }^{29}, 30$. In the present study a slightly higher perceived benefit score and lower barrier score was observed among the group who has been adherent to adequate $\mathrm{F} \& \mathrm{~V}$ intake, yet the difference was not statistically significant. The recommended $\mathrm{F} \& \mathrm{~V}$ daily intake was the least known issue to students with only $8.2 \%$ giving the correct answer. A comparable frequency was reported from other groups of undergraduate students ${ }^{(21)}$. This low level of knowledge of recommended $\mathrm{F} \& \mathrm{~V}$ requirements may be attributed to the lack of nutritional education in school years in Egypt as previously reported ${ }^{(30)}$. Besides, adequate F\&V consumption seems not to be the norm among Egyptian population (8). Despite the low level of knowledge of student in the current study, healthy food events may have slightly influenced the level of knowledge of students who have heard of it.

In the present study, the barrier score is higher among males and among smokers. A significantly higher benefit score and a significantly lower barrier score were found among $4^{\text {th }}$ grade students compared to students of other educational grades collectively although the mean age was comparable. This may be attributed to the fact that $4^{\text {th }}$ grade students were studying at the community medicine department. Thus, $4^{\text {th }}$ grade students' attitude may have been influenced by exposure to reinforced stimulating environment where multiple healthy food events took place ${ }^{31}$.

The most frequently reported barriers for eating vegetables among medical students in the present study were the concern about pesticide or chemical pollution. These concerns were the least important in a Sri Lankan study at medical and other scientific schools ${ }^{21}$. The high cost of fruits was identified as one of the barriers to their consumption in accordance with other studies ${ }^{21,24}$.

More than half of the students have rated health aspects as the most important motives for $\mathrm{F} \& \mathrm{~V}$ consumption which was a similar opinion of other university student ${ }^{22,24}$. Statements reflecting internal motives to eat healthy featured more prominently in students' responses compared to statements that reflect external motives; as pressure from others or seeking others approval of them.

The healthy food initiative carried out by Community medicine department at the faculty of medicine has provided some forms of physical and economic access to healthy foods to students. A high frequency of students has benefited from the health events or is willing to share in future events, which reflects acceptance of such environmental changes. A previous study emphasized the presence of a healthy food environment and its role in healthier food choices by students ${ }^{2,32}$.

Willingness to try healthy food in future events was shown to be higher among $4^{\text {th }}$ grade students This may be associated with the fact that $4^{\text {th }}$ grade students attend 2 months at the Department of Community medicine; hence they are more frequently exposed and have easier and greater accessibility to healthy food during the successive healthy food events. Females and students who were dieting were enthusiastic about actively taking part in the healthy food events which may be a step towards expanding this initiative.

The habit of eating outdoor is common among adolescence in general ${ }^{\left({ }^{(9)}\right.}$.The current study showed that eating outdoors is frequent among medical students, this poses an opportunity to offer healthy food items at students cafeteria instead of fast food stuffs. According to a number of previous studies, college students have expressed a need for accessible quality healthy foods at a reasonable or subsidized price at university campus ${ }^{21,33,34}$. 
Conclusion: The present study revealed low consumption of $\mathrm{F} \& \mathrm{~V}$ among students irrespective of their knowledge or attitude scores regarding F\&V. On the other hand, it showed that high frequencies of students are willing to purchase healthy food if it is made available and accessible to them. Students' knowledge and perceptions of benefits and barriers of $F \& V$ intake seem to have been positively influenced by the healthy environment in the form of healthy food events conducted by the department of Community medicine.

Recommendations: The infrequent F\&V consumption highlights the need for effective interventions and approaches to encourage students increase their daily intake as per recommendations. Making an outlet for healthy eating inside the campus supported by the faculty administration and with participation of students can be an influencing factor. Greater access to $\mathrm{F} \& \mathrm{~V}$ and nutrition education messages can motivate students adopt healthier life long eating habits.

\section{Acknowledgments}

We express our gratitude to the members of the department of Community, Environmental and Occupational medicine for volunteering their time and effort to organize healthy food events. We extend our thanks to the students who have participated in this study.

\section{References}

1. World Health Organization, WHO (2012a) Promoting a healthy diet for the WHO Eastern Mediterranean Region: userfriendly guide Regional Office for the Eastern Mediterranean ISBN: 978-929021-836-4 (online)

2. Deliens T, Clarys P, De Bourdeaudhuij I et al. (2014) Determinants of eating behaviour in university students: a qualitative study using focus group discussions.BMC Public Health; 14:53
3. Abdel Wahed WY, El-Khashab K, Hassan S. K. (2016) Prevalence of Dyslipidaemia among Healthy University Students: Fayoum Governorate, Egypt. Epidemiology Biostatistics and Public Health; 13(2): 1-19

4. El-Zanaty et al 2014 . Egypt Demographic and Health Survey. Available at: https://dhsprogram.com/pubs/pdf/fr302/fr3 02.pdf

5. USDA Food patterns, Healthy US. (2015) Estimated calorie needs/day by age, sex and physical activity level. Available at:

https://health.gov/dietaryguidelines/2015/g uidelines/appendix-2/ (accessed Sept 2015) also available at: https://www. cnpp.usda.gov/sites/default/files/usda food _patterns/EstimatedCalorieNeedsPerDayT able.pdf

6. FAB survey (2009) Synovate Global Opinion Panels, Marie Brighton Panel Director accessed at: http://cancercontrol. cancer.gov/brp/hbrb/fab/docs/FAB_Main annotated.pdf. (Accessed in 2012)

7. Al Ani MF, Al Subhi LK and Bose S. (2016) Consumption of fruits and vegetables among adolescents: a multinational comparison of eleven countries in the Eastern Mediterranean Region. British journal of nutrition; 116 (10):1799-1806

8. World Health Organization WHO, 2012b STEPS chronic disease risk factor surveillance: Egypt STEPS survey 20112012 fact sheet Available at: http://www.who.int/chp/steps/2011-

2012_Egypt_FactSheet.pdf (Accessed Feb 2014)

9. Tayel, DI, El-Sayed NA, El-Sayed, NA. (2013) Dietary pattern and blood pressure levels of adolescents in Sohag. Egypt Journal of the Egyptian Public Health Association; 88(2):97-103

10. Abdel-Hady D, Abdel-Hady ElGilany, Sarraf B. (2014) Dietary habits of adolescent students in Mansoura, Egypt. 
International Journal of Collaborative

Research on Internal Medicine \& Public Health; 6 (6):132-144

11. El Ansari W. and Berg-Beckhoff G. (2017) Country and Gender specific Achievement of Healthy Nutrition and Physical Activity Guidelines: Latent Class Analysis of 6266 University Students in Egypt, Libya, and Palestine Nutrients; 9(7): 738

12. Rieth MA, Moreira MB, Fuchs FD, et al. (2012) Fruits and vegetables intake and characteristics associated among adolescents from Southern Brazil. Nutr J; 16(11):95

13. Ganasegeran K, Al-Dubai SA, Qureshi A.M, et al. (2012) Social and psychological factors affecting eating habits among university students in a Malaysian medical school: a crosssectional study. Nutr J; 11:48

14. Layade A.A., Adeoye I.B. (2014) Fruit and vegetable consumption among students of tertiary institutions in Oyo state, RJOAS; 6(30):

15. AL-Otaibi HH. (2014) The Pattern of Fruit and Vegetable Consumption among Saudi University Students. Global Journal of Health Science; 6(2):155-162

16. Elsoadaa SS, Abdelhafez AM, Naeem M. et al. (2013) Consumption of Fruits and Vegetables among UmmAl-Qura University Students in Makkah, Saudi Arabia: A cross - section study. Life Science Journal; 10(4): 223-231. At http://www.lifesciencesite.com

17. Alsunni A A. and Ahmed Badar (2015) Fruit and vegetable consumption and its determinants among Saudi university students. Journal of Taibah University Medical Sciences, 10(2): 201207

18. Story M, Kaphingst KM, RobinsonO'Brien et al. (2008) Creating healthy food and eating environments: policy and environmental approaches. Annu Rev Public Health; 29:253-72
19. French SA and Stables G. (2003) Environmental interventions to promote vegetable and fruit consumption among youth in school settings. Preventive Medicine; 37(6):593-610 at: http://www.sciencedirect.com/science/artic le/pii/S0091743503002123

20. Hussein R.A. (2011) Can knowledge alone predict vegetable and fruit consumption among adolescents? A transtheoretical model perspective. J Egypt Public Health Assoc; 86(5-6):95-103

21. Perera T. and MadhujithT. (2012) The Pattern of Consumption of Fruits and Vegetables by Undergraduate Students: A Case Study. Tropical Agricultural Research; 23 (3): $261-271$.

22. El-Ahmady SH and El-Wakeel L.(2017) The Effects of Nutrition Awareness and Knowledge on Health Habits and Performance Among Pharmacy Students in Egypt. Journal of Community Health;42(2):213-220

23. El Ansari W. and Berg-Beckhoff G. (2015) Nutritional Correlates of Perceived Stress among University Students in Egypt. Int. J. Environ. Res. Public Health; 12(11): 14164-14176.

24. Epuru S, Eideh A, AlBayoudh A et al. (2014) Fruit and vegetable consumption trends among the female university students in Saudi Arabia. European Scientific Journal; 10 (12):1857 - 7881

25. Chourdakis M, Tzellos T, Papazisis G, et al. (2010) Eating habits, health attitudes and obesity indices among medical students in northern Greece. Appetite; 55(3):722-5.

26. Beech BM, Rice R., Myers L. et al. (1999) Knowledge, attitudes, and practices related to fruit and vegetable consumption of high school students. J Adolesc Health; 24(4): 244-50.

27. Unüsan N. (2004) Fruit and vegetable consumption among Turkish university students. Int J VitamNutr Res; 74(5):3418.Bruening M, Kubik MY, Kenyon D, et al. (2010) Perceived barriers mediate the 
28. association between self-efficacy and fruit and vegetable consumption among students attending alternative high schools. J Am Diet Assoc; 110(10): 1542-6.

29. Lytle LA, Varnell S, Murray DM, et al. (2003) Predicting adolescents' intake of fruits and vegetables. J NutrEducBehav; 35(4):170-5.

30. Tawfik SE, Ez elarab HS, Fahmy WA and Meky FA (2015) Evaluation of Nutrition Education Program among Egyptian Adolescents School Children (11-14 years old) The Egyptian Journal of Community Medicine; 33(4):67-79

31. Hubley JH. (1984) Principles of health education, British Medical Journal; 289:1054-1056
32. Terry-McElrath Yvonne M., O'Malley Patrick M., and Johnston Lloyd D. (2014) Accessibility over Availability: Associations between the school food environment and student fruit and green vegetable consumption. Childhood Obesity; 10(3): 241-250.

33. Ali H.I, Jarrar A.H, Abo-El-Enen M, et al. (2015) Students' perspectives on promoting healthful food choices from campus vending machines: a qualitative interview study. BMC Public Health; 15:512.

34. Holt M., Monk R., Powell S., et al (2015) Student perceptions of a healthy university. Public Health; 129(6):674-83 
Table (1) Socio demographic characteristics of the studied sample of students $(\mathrm{N}=473)$

\begin{tabular}{|c|c|c|c|c|}
\hline Character & Mean & $\begin{array}{l}\text { Standard } \\
\text { deviation }\end{array}$ & Minimum & Maximum \\
\hline Age in years & 20.47 & 1.35 & 17 & 27 \\
\hline & Number & Percent & & \\
\hline $\begin{array}{l}\text { Gender } \\
\text { Male } \\
\text { Female } \\
\end{array}$ & $\begin{array}{l}210 \\
263 \\
\end{array}$ & $\begin{array}{l}44.40 \\
55.60 \\
\end{array}$ & & \\
\hline $\begin{array}{l}\text { Grade } \\
4^{\text {th }} \text { year } \\
\text { Other educational years }\end{array}$ & $\begin{array}{l}291 \\
182 \\
\end{array}$ & $\begin{array}{l}61.52 \\
38.48\end{array}$ & & \\
\hline $\begin{array}{l}\text { Smoking } \\
\text { Non Smoker } \\
\text { Smoker }\end{array}$ & $\begin{array}{r}414 \\
59 \\
\end{array}$ & $\begin{array}{l}87.53 \\
12.47 \\
\end{array}$ & & \\
\hline $\begin{array}{l}\text { Eating outdoors } \\
\text { Yes } \\
\text { No }\end{array}$ & $\begin{array}{l}353 \\
120 \\
\end{array}$ & $\begin{array}{r}74.63 \\
25.37 \\
\end{array}$ & & \\
\hline & Mean & $\begin{array}{l}\text { Standard } \\
\text { deviation }\end{array}$ & Minimum & Maximum \\
\hline Weight in kg & 69.3 & 14.74 & 28 & 130 \\
\hline Height in cm & 169.02 & 10.39 & 130 & 204 \\
\hline & Number & Percent & & \\
\hline $\begin{array}{l}\text { Body Mass Index (BMI)* } \\
\text { Underweight } \\
\text { Normal } \\
\text { Overweight } \\
\text { Obese }\end{array}$ & $\begin{array}{r}22 \\
283 \\
128 \\
40\end{array}$ & $\begin{array}{r}4.74 \\
59.75 \\
26.98 \\
8.54\end{array}$ & & \\
\hline $\begin{array}{l}\text { Currently on a Diet regimen } \\
\text { Yes } \\
\text { No }\end{array}$ & $\begin{array}{l}318 \\
155\end{array}$ & $\begin{array}{l}67.23 \\
32.77\end{array}$ & & \\
\hline
\end{tabular}

*BMI was calculated based on students' self-reported weight and height 
Table (2) Nutritional Knowledge of students regarding fruits and vegetables daily requirements

\begin{tabular}{|l|r|r|}
\hline Item & Number & Percent \\
\hline Daily Caloric intake & & \\
Incorrect & 275 & 58.14 \\
Correct & 198 & 41.86 \\
\hline Daily F\&V servings & 434 & \\
Incorrect & 39 & 81.75 \\
Correct & & \\
\hline Daily fruit cups & 323 & 68.29 \\
Incorrect & 150 & 31.71 \\
Correct & & \\
\hline Daily vegetable cups & 342 & 72.30 \\
Incorrect & 131 & 27.70 \\
Correct & 473 & 100.00 \\
\hline Total & & \\
\hline
\end{tabular}

Table (3): Fruit and vegetable daily intake among students

\begin{tabular}{|l|r|r|r|r|}
\hline \multirow{2}{*}{\multicolumn{1}{c|}{ Daily Intake* }} & \multicolumn{2}{c|}{ Vegetables } & \multicolumn{2}{c|}{ Fruits } \\
\cline { 2 - 5 } & Number & Percent & Number & \multicolumn{1}{c|}{ Percent } \\
\hline Not consumed & 46 & 9.73 & 45 & 9.51 \\
\hline Inadequate & 249 & 52.64 & 274 & 57.93 \\
\hline Adequate & 116 & 24.52 & 110 & 23.26 \\
\hline Exceeding adequate amounts & 62 & 13.11 & 44 & 9.30 \\
\hline
\end{tabular}

*Inadequate ( $<2$ cups daily), adequate $(2-3$ cups/day), excess ( $>3$ cups day) 
Table (4): Students 'agreement* to statements assessing the benefits, barriers and motives to fruit and vegetable consumption

\begin{tabular}{|l|l|l|}
\hline Benefits of vegetable consumption & N= 473 & Percent \\
\hline Vegetables help prevent diseases & 408 & \\
\hline Vegetables are a substitute for unhealthy food & 384 & 86.26 \\
\hline Vegetables are always available & 365 & 81.18 \\
\hline Vegetables make one feel better & 360 & 77.17 \\
\hline Vegetables help maintain weight & 354 & 76.11 \\
\hline Benefits of fruit consumption & $\mathbf{N}$ & 74.84 \\
\hline Fruits make diet more varied & 403 & Percent \\
\hline Fruits help prevent disease & 394 & 85.20 \\
\hline Fruits make one feel better & 385 & 83.30 \\
\hline Fruits always available & 365 & 81.40 \\
\hline Fruits are a substitute for unhealthy food & 349 & 77.17 \\
\hline Fruits help maintain weight & 333 & 73.78 \\
\hline Barriers to vegetables consumption & $\mathbf{N}$ & 70.40 \\
\hline Vegetables tasteless & 287 & Percent \\
\hline Vegetables spoil quickly & 276 & 60.68 \\
\hline Vegetables take time to buy & 248 & 58.35 \\
\hline Vegetables chemically polluted & 235 & 52.43 \\
\hline Vegetables expensive & 123 & 49.68 \\
\hline Barriers to fruit consumption & $\mathbf{N}$ & 26 \\
\hline Fruits chemically polluted & 241 & Percent \\
\hline Fruits spoil quickly & 233 & 50.95 \\
\hline Fruits expensive & 202 & 49.26 \\
\hline Fruits takes time to buy & 200 & 42.71 \\
\hline Fruits Tasteless & 142 & 42.28 \\
\hline Motives for fruit and vegetable consumption & $\mathbf{N}$ & 30.02 \\
\hline - Intrinsic motives: & & Percent \\
\hline Tood thing for my health & 264 & \\
\hline Feel better about myself & 255 & 55.81 \\
\hline Choice I really want to make & 243 & 53.91 \\
\hline To feel in control of myself & 222 & 51.37 \\
\hline - Extrinsic motives: & 221 & 46.93 \\
\hline To set a good example & & 46.72 \\
\hline Wressure from others & 133 & \\
\hline & 107 & 28.12 \\
\hline Agthers to approve of me & 102 & 22.62 \\
\hline
\end{tabular}

*Agreement was considered for students who answered "Agree" and "Strongly agree" in the Likert scale 
Table (5): Relation between consumption of fruits and vegetables and other scores (knowledge, motivation, perceived benefits and barriers)

\begin{tabular}{|l|r|r|r|r|c|}
\hline \multirow{2}{*}{} & \multicolumn{4}{|c|}{$\begin{array}{c}\text { Adherence to the } \\
\text { recommended intake* }\end{array}$} \\
\cline { 2 - 6 } & \multicolumn{2}{|c|}{$\begin{array}{c}\text { Adherent } \\
\mathbf{N}=\mathbf{1 1 0}\end{array}$} & $\begin{array}{c}\text { Non Adherent } \\
\mathbf{N = 3 6 3}\end{array}$ & $\begin{array}{c}\mathbf{P} \\
\text { value }^{+}\end{array}$ \\
\hline Knowledge score percent (Mean \pm SD) & 28.40 & 26.94 & 28.0 & 26.63 & 0.902 \\
\hline Motivation score percent (Mean \pm SD) & 58.65 & 18.65 & 60.13 & 20.00 & 0.534 \\
\hline Perceived Benefits score percent (Mean \pm SD) & 85.17 & 11.44 & 83.56 & 11.79 & 0.247 \\
\hline Perceived Barriers score percent (Mean \pm SD) & 59.13 & 18.29 & 62.54 & 15.97 & 0.079 \\
\hline
\end{tabular}

*Recommended intake of at least 2.5 cups of vegetables and 2 cups of fruits equivalent to 5 servings of fruits and vegetables daily

${ }^{\dagger}$ Independent samples $t$ test was used 
Table (6a): Factors affecting students' knowledge and attitude scores (motivation, barriers and benefits)

\begin{tabular}{|c|c|c|c|c|c|c|c|c|c|c|c|c|}
\hline \multirow{2}{*}{ Variables } & \multicolumn{2}{|c|}{ Knowledge } & \multirow[b]{2}{*}{$P$ value } & \multicolumn{3}{|c|}{ Motivation } & \multirow[b]{2}{*}{ Mean\% } & \multirow{2}{*}{$\begin{array}{l}\text { Benefits } \\
\text { SD } \\
\end{array}$} & \multirow[b]{2}{*}{$P$ value } & \multirow[b]{2}{*}{ Mean\% } & \multirow{2}{*}{$\begin{array}{l}\text { Barriers } \\
\text { SD }\end{array}$} & \multirow[b]{2}{*}{$P$ value } \\
\hline & Mean\% & SD & & Mean\% & SD & $P$ value & & & & & & \\
\hline $\begin{array}{l}\text { Grade } \\
4^{\text {th }} \text { year } \\
\text { Other educational years }\end{array}$ & $\begin{array}{l}29.73 \\
25.52 \\
\end{array}$ & $\begin{array}{l}27.22 \\
25.67 \\
\end{array}$ & 0.108 & $\begin{array}{l}61.07 \\
57.74 \\
\end{array}$ & $\begin{array}{l}19.72 \\
19.83 \\
\end{array}$ & 0.081 & $\begin{array}{l}85.24 \\
81.85 \\
\end{array}$ & $\begin{array}{l}10.9 \\
12.54\end{array}$ & $0.003 *$ & $\begin{array}{l}60.12 \\
64.36 \\
\end{array}$ & $\begin{array}{l}16.19 \\
16.75 \\
\end{array}$ & $0.011^{*}$ \\
\hline $\begin{array}{l}\text { Gender } \\
\text { Male } \\
\text { Female }\end{array}$ & $\begin{array}{l}31.79 \\
25.17\end{array}$ & $\begin{array}{l}25.89 \\
26.99 \\
\end{array}$ & $0.009 *$ & $\begin{array}{l}60.32 \\
59.36 \\
\end{array}$ & $\begin{array}{l}19.86 \\
19.78 \\
\end{array}$ & 0.615 & $\begin{array}{l}83.09 \\
84.61 \\
\end{array}$ & $\begin{array}{l}11.42 \\
11.84 \\
\end{array}$ & 0.194 & $\begin{array}{l}63.82 \\
60.1 \\
\end{array}$ & $\begin{array}{l}16.82 \\
16.12 \\
\end{array}$ & $0.016^{*}$ \\
\hline $\begin{array}{l}\text { Smoking } \\
\text { No } \\
\text { Yes } \\
\end{array}$ & $\begin{array}{l}27.95 \\
29.24 \\
\end{array}$ & $\begin{array}{l}26.78 \\
26.20 \\
\end{array}$ & 0.759 & $\begin{array}{l}60.19 \\
56.97 \\
\end{array}$ & $\begin{array}{l}19.52 \\
21.67 \\
\end{array}$ & 0.275 & $\begin{array}{l}84.29 \\
81.44 \\
\end{array}$ & $\begin{array}{l}11.45 \\
12.91 \\
\end{array}$ & 0.131 & $\begin{array}{l}60.94 \\
67.46 \\
\end{array}$ & $\begin{array}{l}16.48 \\
15.81 \\
\end{array}$ & $0.009 *$ \\
\hline $\begin{array}{l}\text { Eating outdoors } \\
\text { Yes } \\
\text { No } \\
\end{array}$ & $\begin{array}{l}26.70 \\
32.26 \\
\end{array}$ & $\begin{array}{l}25.99 \\
28.37 \\
\end{array}$ & 0.064 & $\begin{array}{l}59.2 \\
61.52 \\
\end{array}$ & $\begin{array}{l}19.66 \\
20.21 \\
\end{array}$ & 0.303 & $\begin{array}{l}83.72 \\
84.57 \\
\end{array}$ & $\begin{array}{l}12.12 \\
10.25 \\
\end{array}$ & 0.513 & $\begin{array}{l}62.20 \\
60.43 \\
\end{array}$ & $\begin{array}{l}16.91 \\
15.31 \\
\end{array}$ & 0.327 \\
\hline $\begin{array}{l}\text { Overweight/ obese } \\
\text { No } \\
\text { Yes }\end{array}$ & $\begin{array}{l}27.82 \\
28.64 \\
\end{array}$ & $\begin{array}{l}27.09 \\
26.01 \\
\end{array}$ & 0.781 & $\begin{array}{l}59.64 \\
60.05 \\
\end{array}$ & $\begin{array}{l}19.17 \\
20.96 \\
\end{array}$ & 0.839 & $\begin{array}{l}84.24 \\
83.38 \\
\end{array}$ & $\begin{array}{l}11.17 \\
12.53 \\
\end{array}$ & 0.508 & $\begin{array}{l}60.91 \\
63.28 \\
\end{array}$ & $\begin{array}{l}16.88 \\
15.78 \\
\end{array}$ & 0.184 \\
\hline $\begin{array}{l}\text { On Diet regimen } \\
\text { No } \\
\text { Yes }\end{array}$ & $\begin{array}{c}28.29 \\
28.02 \\
\end{array}$ & $\begin{array}{l}25.17 \\
27.43 \\
\end{array}$ & 0.928 & $\begin{array}{l}56.22 \\
61.53 \\
\end{array}$ & $\begin{array}{l}19.46 \\
19.76 \\
\end{array}$ & $0.008 *$ & $\begin{array}{l}82.85 \\
84.46 \\
\end{array}$ & $\begin{array}{l}12.32 \\
11.32 \\
\end{array}$ & 0.169 & $\begin{array}{l}60.63 \\
62.30 \\
\end{array}$ & $\begin{array}{l}17.09 \\
16.23 \\
\end{array}$ & 0.331 \\
\hline
\end{tabular}

Independent $\mathbf{t}$ test was used

*Statistical significance level $\mathbf{P}<0.05$ 
Table (6b): Factors affecting students' knowledge and attitude scores (motivation, barriers and benefits)

\begin{tabular}{|c|c|c|c|c|c|c|c|c|c|c|c|c|}
\hline \multirow[b]{2}{*}{ Variables } & \multicolumn{3}{|c|}{ Knowledge } & \multicolumn{3}{|c|}{ Motivation } & \multicolumn{3}{|c|}{ Benefits } & \multicolumn{3}{|c|}{ Barriers } \\
\hline & Mean\% & SD & $P$ value & Mean \% & SD & $P$ value & Mean\% & SD & $\begin{array}{l}P \\
\text { value }\end{array}$ & Mean\% & SD & $\begin{array}{l}\mathbf{P} \\
\text { value }\end{array}$ \\
\hline $\begin{array}{l}\text { Knew of healthy food day } \\
\text { No } \\
\text { Yes }\end{array}$ & $\begin{array}{l}23.64 \\
30.56\end{array}$ & $\begin{array}{l}26.02 \\
26.72\end{array}$ & $0.008^{*}$ & $\begin{array}{l}54.91 \\
62.46\end{array}$ & $\begin{array}{l}21.4 \\
18.4\end{array}$ & $0.001 *$ & $\begin{array}{l}82.57 \\
84.69\end{array}$ & $\begin{array}{l}12.63 \\
11.08\end{array}$ & 0.067 & $\begin{array}{l}65.16 \\
59.88\end{array}$ & $\begin{array}{l}16.24 \\
16.44\end{array}$ & $0.001 *$ \\
\hline $\begin{array}{l}\text { Ever tried buying } \\
\text { No } \\
\text { Yes }\end{array}$ & $\begin{array}{l}28.13 \\
28.11\end{array}$ & $\begin{array}{l}26.97 \\
26.29\end{array}$ & 0.992 & $\begin{array}{l}58.43 \\
62.23\end{array}$ & $\begin{array}{l}20.67 \\
18.07\end{array}$ & 0.049 & $\begin{array}{l}83.54 \\
84.67\end{array}$ & $\begin{array}{l}11.52 \\
11.94\end{array}$ & 0.339 & $\begin{array}{l}61.14 \\
62.84\end{array}$ & $\begin{array}{l}16.88 \\
15.91\end{array}$ & 0.320 \\
\hline $\begin{array}{l}\text { Willing to buy } \\
\text { No } \\
\text { Yes }\end{array}$ & $\begin{array}{l}27.86 \\
28.42\end{array}$ & $\begin{array}{l}26.86 \\
26.51\end{array}$ & 0.838 & $\begin{array}{l}58.66 \\
61.26\end{array}$ & $\begin{array}{l}20.09 \\
19.43\end{array}$ & 0.182 & $\begin{array}{l}82.66 \\
85.60\end{array}$ & $\begin{array}{l}12.66 \\
10.07\end{array}$ & 0.019 & $\begin{array}{l}63.83 \\
59.05\end{array}$ & $\begin{array}{l}15.9 \\
17.01\end{array}$ & $0.002 *$ \\
\hline $\begin{array}{l}\text { Willing to participate } \\
\text { No } \\
\text { Yes }\end{array}$ & $\begin{array}{l}27.02 \\
29.51\end{array}$ & $\begin{array}{l}26.26 \\
27.22\end{array}$ & 0.337 & $\begin{array}{l}56.64 \\
63.82\end{array}$ & $\begin{array}{l}19.43 \\
19.66\end{array}$ & $<0.001 *$ & $\begin{array}{l}82.19 \\
86.17\end{array}$ & $\begin{array}{l}12.48 \\
10.17\end{array}$ & $0.001 *$ & $\begin{array}{l}63.37 \\
59.67\end{array}$ & $\begin{array}{l}16.34 \\
16.68 \\
\end{array}$ & $0.020 *$ \\
\hline
\end{tabular}

Independent $t$ test was used

*Statistical significance level $P<0.05$ 
Table (7) Factors that may be associated with students' consumption of F\&V (practice)

\begin{tabular}{|c|c|c|c|c|c|c|}
\hline & \multicolumn{5}{|c|}{$\begin{array}{l}\text { Adherence to the recommended } \\
\text { intake of } \mathbf{F} \& \mathbf{V}^{*} \text { (Practice) }\end{array}$} & \multirow{3}{*}{ OR $(95 \%$ CI $)$} \\
\hline & \multicolumn{2}{|c|}{ Adherent $\mathrm{N}=110$} & \multicolumn{2}{|c|}{ Non Adherent $\mathbf{N}=363$} & \multirow[b]{2}{*}{$\begin{array}{l}\mathbf{P} \\
\text { value }^{+}\end{array}$} & \\
\hline & Number & Row \% & Number & Row \% & & \\
\hline $\begin{array}{l}\text { Grade } \\
\text { 4th grade }\end{array}$ & 64 & 21.99 & 227 & 78.01 & \multirow[t]{2}{*}{0.441} & $0.834(0.54-1.28)$ \\
\hline $\begin{array}{ll}\text { Other } & \text { education } \\
\text { grades } & \end{array}$ & 46 & 25.27 & 136 & 74.73 & & \\
\hline $\begin{array}{l}\text { Gender } \\
\text { Male }\end{array}$ & 57 & 27.14 & 153 & 72.86 & \multirow[t]{2}{*}{0.074} & $1.476(0.96-2.26)$ \\
\hline Female & 53 & 20.15 & 210 & 79.85 & & \\
\hline $\begin{array}{l}\text { Smoking } \\
\text { No }\end{array}$ & 98 & 23.67 & 316 & 76.33 & \multirow[t]{2}{*}{0.571} & $0.823(0.42-1.614)$ \\
\hline Yes & 12 & 20.34 & 47 & 79.66 & & \\
\hline $\begin{array}{l}\text { Eating outdoors } \\
\text { Yes }\end{array}$ & 84 & 23.80 & 269 & 76.20 & \multirow[t]{2}{*}{0.502} & $0.842(0.50-1.39)$ \\
\hline No & 26 & 21.67 & 94 & 78.33 & & \\
\hline $\begin{array}{l}\text { Overweight/ obese } \\
\text { No }\end{array}$ & 76 & 24.92 & 229 & 75.08 & \multirow[t]{2}{*}{0.304} & $0.788(0.5-1.24)$ \\
\hline Yes & 34 & 20.24 & 134 & 79.76 & & \\
\hline $\begin{array}{l}\text { On Diet regimen } \\
\text { No }\end{array}$ & 40 & 25.81 & 115 & 74.19 & \multirow[t]{2}{*}{0.251} & $0.77(0.49-1.20)$ \\
\hline Yes & 70 & 22.01 & 248 & 77.99 & & \\
\hline $\begin{array}{l}\text { Knew of healthy } \\
\text { food day }\end{array}$ & 36 & 2143 & 132 & 7857 & \multirow{2}{*}{0.344} & $1247(078-107)$ \\
\hline Yes & $\frac{50}{74}$ & $\frac{21.45}{24.26}$ & $\frac{152}{231}$ & $\begin{array}{l}10.51 \\
75.74\end{array}$ & & $1.24 /(0.10-1.97)$ \\
\hline $\begin{array}{l}\text { Ever tried buying } \\
\text { healthy food } \\
\text { No }\end{array}$ & 70 & 22.77 & 234 & 77.23 & \multirow[t]{2}{*}{0.321} & $1.245(0.80-1.92)$ \\
\hline Yes & 40 & 24.12 & 129 & 75.88 & & \\
\hline $\begin{array}{l}\text { Willing to buy in } \\
\text { coming events } \\
\text { No }\end{array}$ & 64 & 23.97 & 203 & 76.03 & \multirow{2}{*}{0.751} & $0.933(0.60-1.43)$ \\
\hline Yes & 46 & 22.33 & 160 & 77.67 & & \\
\hline $\begin{array}{ll}\text { Willing } & \text { to } \\
\text { participate } \\
\text { No }\end{array}$ & 67 & 25.19 & 199 & 74.81 & \multirow[t]{2}{*}{0.313} & $0.8(0.518-1.235)$ \\
\hline Yes & 43 & 20.77 & 164 & 79.23 & & \\
\hline
\end{tabular}

OR (95\% CI): Odds Ratio (95\% Confidence interval)

*Recommended intake of at least 2.5 cups of vegetables and 2 cups of fruits equivalent to 5 servings of fruits and vegetables daily.

${ }^{\dagger}$ Chi squared test was used 
Table (8): Association between demographic characters and students' participation in healthy food events

\begin{tabular}{|c|c|c|c|c|c|c|c|c|c|c|c|c|}
\hline & \multicolumn{5}{|c|}{$\begin{array}{l}\text { Ever tried buying healthy food } \\
\qquad N=169\end{array}$} & \multicolumn{3}{|c|}{$\begin{array}{l}\text { Willing to buy in coming } \\
\text { events } N=206\end{array}$} & \multicolumn{4}{|c|}{$\begin{array}{l}\begin{array}{l}\text { Willing to participate } \\
\mathrm{N}=207\end{array} \\
\end{array}$} \\
\hline & $\mathrm{N}$ & Row $\%$ & $\begin{array}{c}\mathrm{P} \\
\text { value }\end{array}$ & OR & $\mathrm{N}$ & Row $\%$ & $\begin{array}{c}\mathrm{P} \\
\text { value }\end{array}$ & OR & $\mathrm{N}$ & $\begin{array}{c}\text { Row } \\
\%\end{array}$ & $\begin{array}{c}\mathrm{P} \\
\text { value }\end{array}$ & OR \\
\hline $\begin{array}{l}\text { Grade } \\
\text { Other than } 4^{\text {th }} \text { grade }\end{array}$ & 64 & 35.16 & 0.072 & $1.095(0.74-1.60)$ & 71 & 39.01 & $0.032 *$ & $1.268(0.87-1.84)$ & 83 & 45.60 & 0.060 & $0.911(0.62-1.32)$ \\
\hline $4^{\text {th }}$ grade & 105 & 36.08 & & & 135 & 46.39 & & & 124 & 42.61 & & \\
\hline $\begin{array}{l}\text { Gender } \\
\text { Female }\end{array}$ & 91 & 34.60 & 0.059 & $1.187(0.81-1.72)$ & 113 & 42.97 & 0.069 & $0.947(0.65-1.36)$ & 125 & 47.53 & $0.014 *$ & $0.711(0.49-1.02)$ \\
\hline Male & 78 & 37.14 & & & 93 & 44.29 & & & 82 & 39.05 & & \\
\hline $\begin{array}{l}\text { Smoking } \\
\text { No }\end{array}$ & 141 & 34.06 & $0.013^{*}$ & $1.632(0.94-2.82)$ & 184 & 44.44 & 0.069 & $0.758(0.43-1.33)$ & 181 & 43.72 & 0.111 & $1.076(0.62-1.86)$ \\
\hline Yes & 28 & 47.46 & & & 22 & 37.29 & & & 26 & 44.07 & & \\
\hline $\begin{array}{l}\text { Eating outdoors } \\
\text { Yes }\end{array}$ & 135 & 38.24 & $0.019 *$ & $0.643(0.41-1)$ & 153 & 43.34 & 0.082 & $1.031(0.67-1.56)$ & 160 & 45.33 & $0.043^{*}$ & $.738(0.48-1.12)$ \\
\hline No & 34 & 28.33 & & & 53 & 44.17 & & & 47 & 39.17 & & \\
\hline $\begin{array}{l}\text { Overweight/obese } \\
\text { No }\end{array}$ & 107 & 35.08 & 0.077 & $1.113(0.77-1.66)$ & 133 & 43.61 & 0.073 & $0.952(0.65-1.39)$ & 133 & 43.61 & 0.071 & $1.033(0.70-1.50)$ \\
\hline Yes & 62 & 36.90 & & & 73 & 43.45 & & & 74 & 44.05 & & \\
\hline $\begin{array}{l}\text { On Diet regimen } \\
\text { No }\end{array}$ & 50 & 32.26 & $0.040^{*}$ & $1.175(0.79-1.74)$ & 63 & 40.65 & 0.056 & $1.163(0.78-1.71)$ & 63 & 40.65 & $0.046^{*}$ & $1.24(0.84-0.829)$ \\
\hline Yes & 119 & 37.42 & & & 143 & 44.97 & & & 144 & 45.28 & & \\
\hline
\end{tabular}

OR: Odds Ratio, Chi squared test was used 


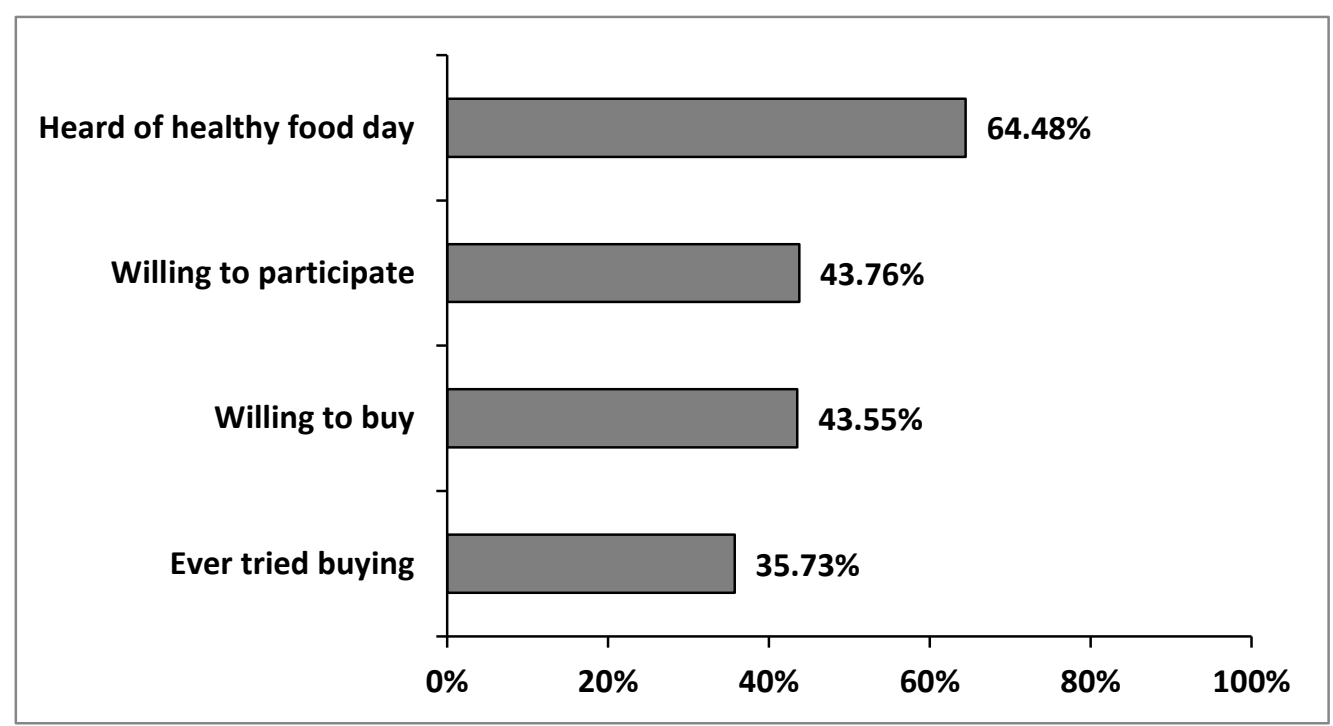

Figure (a): Participation in the healthy food day events 